\author{
LVOV MATHEMATICAL SCHOOL \\ IN THE PERIOD 1915-45 AS SEEN TODAY \\ BANACH CENTER PUBLICATIONS, VOLUME 87 \\ INSTITUTE OF MATHEMATICS \\ POLISH ACADEMY OF SCIENCES \\ WARSZAWA 2009
}

\title{
THE LVOV YEARS OF WACŁAW SIERPIŃSKI
}

\author{
ANDRZEJ SCHINZEL \\ Mathematical Institute, Polish Academy of Sciences \\ Śniadeckich 8, P.O. Box 21, PL-00-956 Warszawa, Poland \\ E-mail: schinzel@impan.pl
}

\begin{abstract}
An account is given of Sierpiński's activity in Lvov (1908-1918) interrupted by World War I.
\end{abstract}

On obtaining his doctorate at Cracow in 1906 Sierpiński returned to Warsaw. He had been persuaded by J. Puzyna to apply for habilitation at the University of Lvov and, indeed, on July 6, 1908 he obtained there "venia legendi", the right to teach. His habilitation thesis consisted of three papers [1], [2], [3], of which by far the most important was the first. Here Sierpiński proves by Voronoř's method that the number of integer solutions of the inequality $m^{2}+n^{2} \leq x$ is $\pi x+O\left(x^{1 / 3}\right)$. Sierpiński's habilitation lecture entitled "On the notion of correspondence in mathematics" (in Polish) was later published as [7]. A function is defined there as a mental process, which shows that in 1908 Sierpiński was not yet an expert in set theory. In the autumn of 1908 he begun his lectures at the University of Lvov as the so-called private docent (Privatdozent, free reader). As such he did not receive any salary from the university, only a part of the money paid to the university by the students attending his lectures.

In the academic year 1908/9 Sierpiński lectured only on classical subjects, but the next academic year he gave a systematic course of lectures on set theory. This was one of the first such courses in Europe, but not the first as Sierpiński wrote many years later [22], being induced into the error by an opinion of Quido Vetter, historian of mathematics. Earlier courses on set theory had been given by Zermelo, Hausdorff and Landau (see [24]). The content of Sierpiński's lecture was first published in mimeographed form [14] and then, in 1912, as a book [16]. This was in chronological order the fifth book on set theory in the world (see [21], p. 133). It was honoured by the Cracow Academy of Arts and Sciences by the Konstanty Simon prize (1913). Among first students of Sierpiński

2000 Mathematics Subject Classification: Primary 01A72; Secondary 11-03.

The paper is in final form and no version of it will be published elsewhere. 
were Otton Nikodym and Stanisław Ruziewicz and in his seminar (in 1910) participated future professors of philosophy, Kazimierz Ajdukiewicz and Tadeusz Czeżowski.

On July 19, 1910 Sierpiński married Anna Kazimiera Leśniewska. In September he was nominated by the emperor Franz Joseph an associate professor at the University and became head of the second chair of mathematics. In order to make it possible, Sierpiński took the Austrian citizenship. In 1912 the university proposed to the ministry his promotion to full professorship, but the proposal was rejected on financial grounds. Also in 1912 Sierpiński's only child, Mieczysław was born.

In 1913 Sierpiński promoted his formally first Ph.D. student, Stefan Mazurkiewicz and the next year their joint paper [20] appeared, the first of the three joint publications. In summer 1914 Sierpiński visited his parents in law in their property Poznajów in Byelorussia. At the outbreak of World War I he was, as an Austrian citizen, together with his family interned first at Wiatka, then in Moscow. In the autumn of 1917 Sierpińskis escaped from Russia via Finland and via Sweden returned to Lvov. Here Sierpiński lectured at the university for the summer semester of 1918 and then accepted a position in Warsaw.

During the Lvov years Sierpiński published about 70 research papers, four surveys (see [23], pp. 15-50), twelve mimeographed lecture notes [4-6], [8-11], [13-15], [17], [19] and three books [12], [16] and [18]. In January 1910 Sierpiński proved (see [23], 158-160), later than P. Bohl, but independently, the uniform distribution mod 1 of multiples of an irrational number. In February 1911 he studied expansions of real numbers into series (see [23], 236-254) now known as Engel series, although Engel studied them two years later. That was for several years the last research paper of Sierpiński close to number theory, afterwards his interests shifted completely to set theory. This was important not only to him, but to Polish mathematics in general.

\section{References}

[1] W. Sierpiński, O pewnym zagadnieniu z rachunku funkcji asymptotycznych [On a problem of the theory of asymptotic functions], Prace mat.-fiz. 17 (1906), 77-118 (French translation in [23], 73-108).

[2] W. Sierpiński, Sur le développement de l'expression $\sqrt[m]{a}$ en un produit infini, Bull. Intern. Acad. Sci. Lettres Cracovie, Classe Sci. Math. Nat., Sér. A Sci. Math. (1907), 1052-1057, see also [23], 222-226.

[3] W. Sierpiński, Wzór analityczny na pewna funkcję liczbowa [An analytic formula for a certain arithmetic function], Wiadom. Mat. 19 (1908), 77-80.

[4] W. Sierpiński, Teorya liczb [Number theory], Lwów 1908, Kółko matematyczno-fizyczne uczniów Uniwersytetu Cesarza Franciszka I (KMF), 549 pages.

[5] W. Sierpiński, Teorya liczb niewymiernych [Theory of irrational numbers], Lwów 1908, KMF, 304 pages (mimeographed notes).

[6] W. Sierpiński, Teorya liczb zespolonych [Theory of complex numbers], Lwów 1908, KMF, 28 pages (mimeographed notes).

[7] W.Sierpiński, Pojęcie odpowiedniości w matematyce [The notion of correspondence in mathematics], Przegląd Filozoficzny 12 (1909), 8-19. 
[8] W. Sierpiński, Arytmetyczna teorya kwaternionów [Arithmetical theory of quaternions], Lwów 1908, KMF, 47 pages (mimeographed notes).

[9] W.Sierpiński, Rachunek sumacyjny [Calculus of sums], Lwów 1909, KMF, 111 pages (mimeographed notes).

[10] W. Sierpiński, Teorya nieskończonych szeregów, iloczynów i ułamków ciagtych [Theory of infinite series, products and continued fractions], Lwów 1909, KMF, 156 pages (mimeographed notes).

[11] W. Sierpiński, Wstęp do teoryi funkcyj [Introduction to Function Theory], Lwów 1909, KMF, 47 pages (mimeographed notes).

[12] W. Sierpiński, Teorya liczb niewymiernych [Theory of irrational numbers], Warszawa 1910, Biblioteka Matematyczno-Fizyczna, 149 pages.

[13] W. Sierpiński, Analiza wyższa. Rozwijanie funkcyj na szeregi. Wstęp do rachunku różniczkowego i catkowego [Higher Analysis. Expansion of Functions into Series. Introduction to Calculus], Lwów 1910, KMF, 356 pages (mimeographed notes).

[14] W. Sierpiński, Teorya mnogości [Set Theory], Lwów 1910, KMF, 187 pages (mimeographed notes).

[15] W. Sierpiński, Zastosowania teoryi mnogości do analizy [Applications of Set Theory to Analysis], Lwów 1911, KMF, 256 pages (mimeographed notes).

[16] W. Sierpiński, Zarys teorii mnogości [An Outline of Set Theory], Warszawa 1912, Biblioteka Matematyczno-Fizyczna, VIII + 158 pages.

[17] W. Sierpiński, Teorya mnogości II [Set Theory II], Lwów 1913, KMF, 191 pages (mimeographed notes).

[18] W. Sierpiński, Teorya liczb [Number Theory], Warszawa 1914, Biblioteka MatematycznoFizyczna, XIV + 412 pages.

[19] W. Sierpiński, Teoria miary Lebesgue'a [Theory of the Lebesgue Measure], Lwów 1914, KMF, 52 pages (mimeographed notes).

[20] S. Mazurkiewicz and W. Sierpiński, Sur un ensemble superposable avec chacune de ses deux parties, Comptes Rendus Acad. Sci. Paris 158 (1914), 618-619.

[21] W. Sierpiński, Wstęp do teorii mnogości i topologii [An Introduction to the Theory of Sets and Topology], 3. ed., Państwowe Zakłady Wydawnictw Szkolnych, Warszawa 1965.

[22] W. Sierpiński, O polskiej szkole matematycznej [On the Polish School of Mathematics], in: Wkład Polaków do nauki. Nauki ścisłe, Państwowe Wydawnictwo Naukowe, Warszawa 1967, 413-434.

[23] W. Sierpiński, Oeuvres choisies, Tome I, Państwowe Wydawnictwo Naukowe, Warszawa 1974.

[24] M.Zakrzewski, Teoria mnogości [Theory of sets], in: Historia nauki polskiej. Wiek XX. Nauki ściste, Zeszyt pierwszy 84-127, Instytut Historii Nauki PAN, Warszawa 1995. 
